\title{
MODEL OF FUZZY LOGIC FOR SELECTION INFRASTRUCTURAL INVESTMENT PROJECT OF WIND FARM LOCATIONS
}

\author{
Zajim Aljicevic, Aleksandra Kostic, Nedis Dautbasic \& Gunay Karli
}
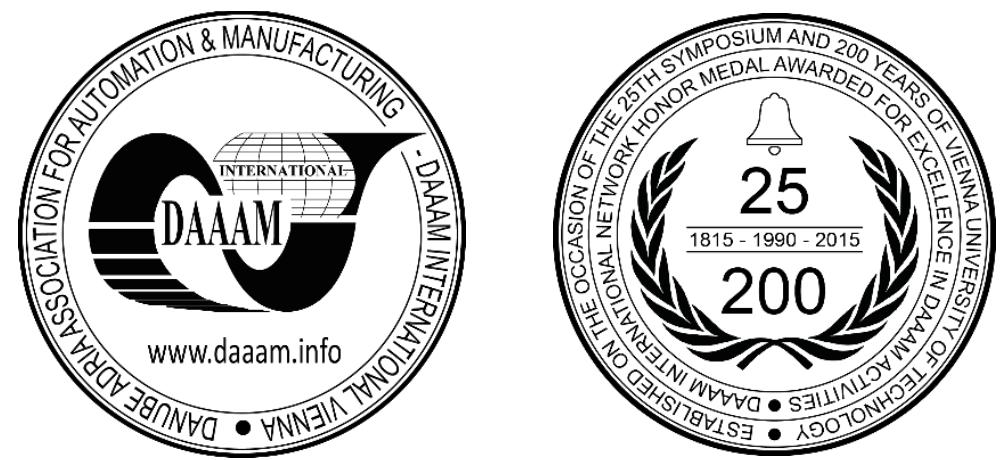

This Publication has to be referred as: Aljicevic, Z[ajim]; Kostic, A[leksandra]; Dautbasic, N[edis] \& Karli, G[unay] (2016). Model of Fuzzy Logic for Selection Infrastructural Investment Project of Wind Farm Locations, Proceedings of the 27th DAAAM International Symposium, pp.0743-0748, B. Katalinic (Ed.), Published by DAAAM International, ISBN 978-3-902734-08-2, ISSN 1726-9679, Vienna, Austria

DOI: $10.2507 / 27$ th.daaam.proceedings. 107

\begin{abstract}
The total energy consumption in world is exponentially increasing. Infrastructural investment in wind energy project is the best solution for resolving energy problem. Selecting the site for wind farm is a complex process involving not only technical requirement, but also physical, economical, social, environmental and political requirements that may result in conflicting objectives, and that's why, it is necessary to create model that provides most desirable location for investing.

The present paper uses fuzzy logic methodology and MATLAB to assess wind sites and decide which sites should be given the highest priority with respect to their benefits and costs. The criterion of evaluation using fuzzy logic is based on different parameters, i.e., wind resources, prevailing wind direction, above ground level, site capacity, soil conditions, site elevation, land cost, land roughness, temperature, cultural and environmental concerns, aviation/telecommunications conflicts, nearby resident's concerns, site environmental issue and distance to transmission line.
\end{abstract}

For verification of our solutions, we had deployed the available data on the wind farm in Podveležje and based on our model, we may conclude that the site selection is quite good.

Keywords: Fuzzy logic; Infrastructural project; Wind farm; Renewable resources; Wind power; Site selection

\section{Introduction}

Increasing environmental concern during the 21th Century has moved the research focus from conventional electricity sources to renewable and alternative energy solutions. In renewable power generation, wind energy has been noted as the fastest-growing energy technology in the world, due to the fact that world has enormous resources of wind energy. Bosnia and Herzegovina also has a big wind potential which need to be used.

At Global Wind Energy Council (GWEC, in April 2016, it is noted that wind power had another record-breaking year. After passing the $50 \mathrm{GW}$ mark for the first time in a single year in 2014, it reached another milestone in 2015 as annual installations topped $63 \mathrm{GW}$, a 22\% increase. By the end of last year, there were about $433 \mathrm{GW}$ of wind power spinning 
around the globe, a cumulative $17 \%$ increase; and wind power supplied more new power generation than any other technology in 2015, according to the IEA[1] (Source: GWEC - Global Wind Energy Council)

Many studies have been proposed to optimize wind power generation. Shata and Hanitsch [2] have evaluated different wind sites in Egypt using classical statistical analysis to estimate the best wind site. Koçak [3] focused entirely on wind speed persistence during weather forecast, site selection for wind turbines and synthetic generation of the wind speed data. Herbert et al [4] developed models for wind resources assessment, site selection and aerodynamic including wake effect to improve the wind turbine performance and to increase its productivity. Lackner et al [5] utilized ground-based measurement devices instead of meteorological towers for wind resource assessment. They investigated the use of a monitoring strategy in more than one site to determine the best wind sites.

This paper utilizes fuzzy logic to evaluate various sites in the bases of their benefits and costs to adopt the higher priority sites in terms of different criteria. The paper is organized so that in Section 2 is given a general overview of the installed capacity of wind power. In Section 3 are given wind characteristics in Bosnia and Herzegovina. In Section 4 is shown fuzzy logic methodology. In Section 5 are presented fuzzy logic rules. In the sixth Section is explained defuzzification. The conclusion was made verification using data on existing wind farm in Podveležje, and plan future research.

\section{Renewable resources}

Today, new renewable resources provide only a small share of global energy production (Figure 1). However, the global market for wind power has been expanding faster than any other sources of renewable energy. The world wind power capacity has been duplicated around twenty five times from just $17.4 \mathrm{GW}$ in 2000 to reach over than $432.8 \mathrm{GW}$ at the end of 2015 (Figure 2).

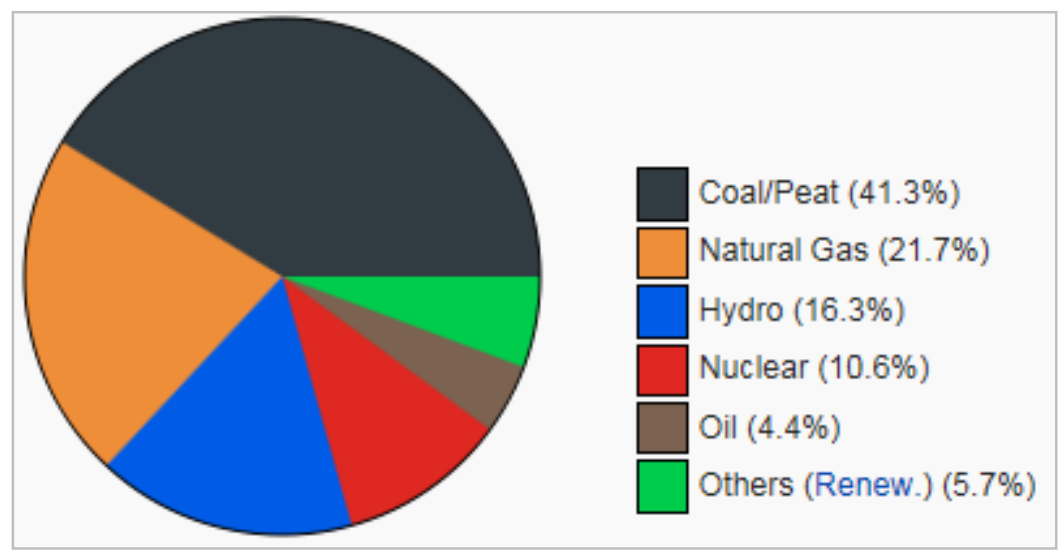

Fig. 1. Shares of world electricity generation (EIA, 2015).

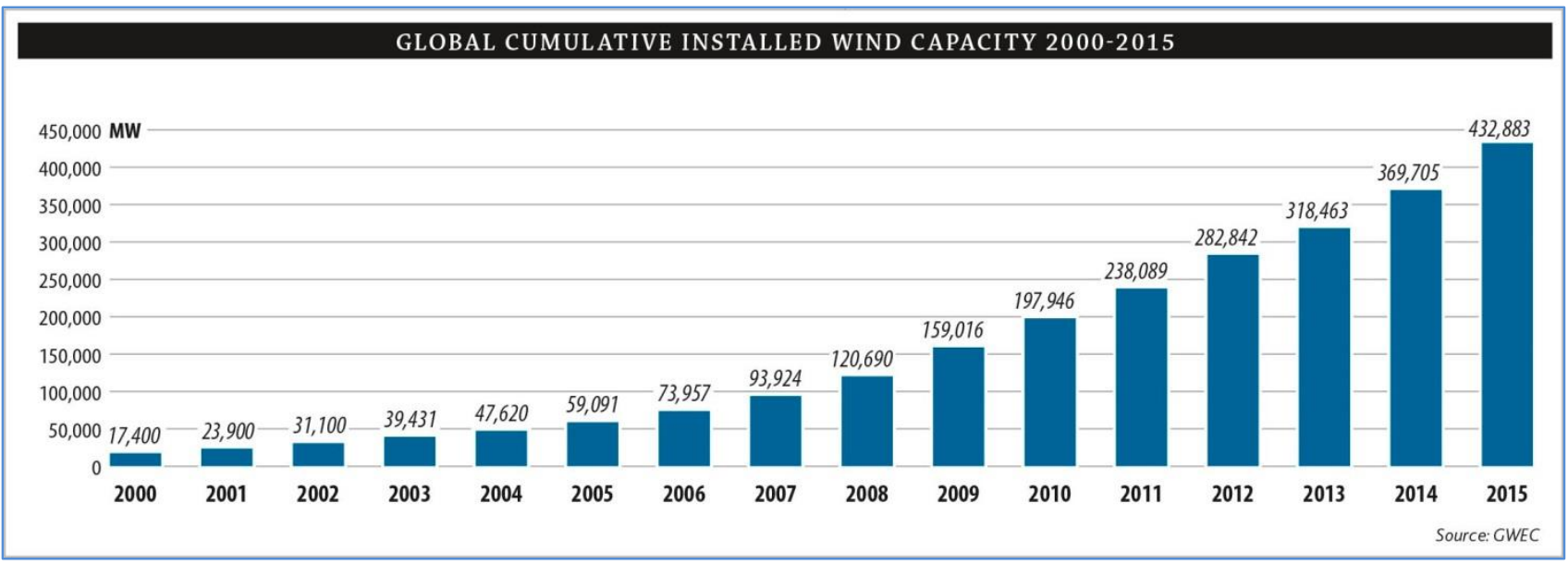

Fig. 2. Global cumulative wind power capacity (Source: GWEC 2015)

In 2015, increase in wind generation was equal to almost half of global electricity growth. This was surprising but welcome news. It became apparent from new IEA analysis revealing that, for the second successive year, global CO2 emissions remained stable despite growth in the world economy. 
It is generally known that we need to invest in wind power. The main problem is how to choose the best location for investment in wind power plants.

This paper utilizes fuzzy logic to evaluate various sites in the bases of their benefits and costs to adopt the higher priority sites in terms of different criteria, i.e., same benefits factors are: wind resources, prevailing wind direction, above ground level, site capacity, site accessibility, soil conditions, site elevation. Cost factors are: land cost, land roughness, temperature, cultural and environmental concerns, aviation/telecommunications conflicts, nearby resident's concerns, site environmental issues (corrosion, humidity), and distance to transmission line, as is used in [6].

\section{Wind characteristics in Bosnia and Herzegovina}

In the previous period in Bosnia and Herzegovina wind characteristics have been measured at weather stations. Study of Energetic sector [7] shows average annual wind speed at height $50 \mathrm{~m}$ above ground for the period 1997-2006. (Figure 3)

Therefore, the first analysis, research and examinations of wind power potential are linked to the area of south Bosnia and Herzegovina. In April 2002 at the location Podveležje Mostar the first measuring station with appropriate equipment is installed, and then the other ones followed. Inclusive to 31.12.2007, at 13 areas the total number of locations where measuring equipment has been installed is 33. [8-10].

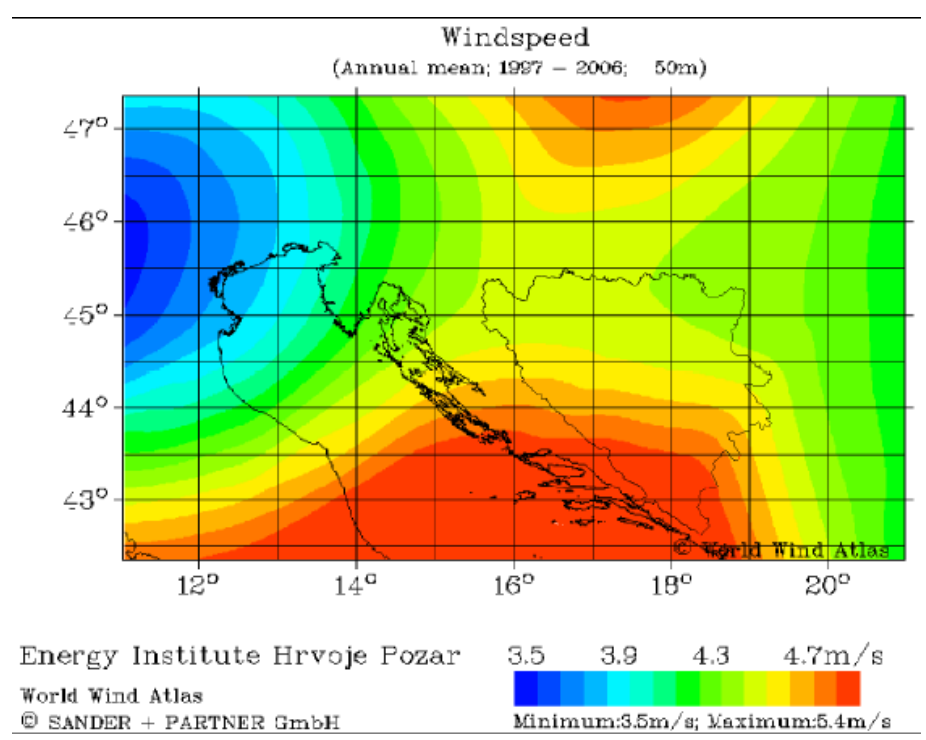

Fig. 3. Average annual wind speed at height $50 \mathrm{~m}$ above ground for the period 1997-2006

\section{Fuzzy logic methodology for decision making}

Fuzzy logic has a wide range of utilizations in decision making since it condenses a large amount of parameters into smaller fuzzy sets [11].

In this paper, we have selected Mamdami method because of its closeness to human understanding, since we had a large number of rules in decision-making.

The Fuzzy input/ output combination is shown in the Figure 4.

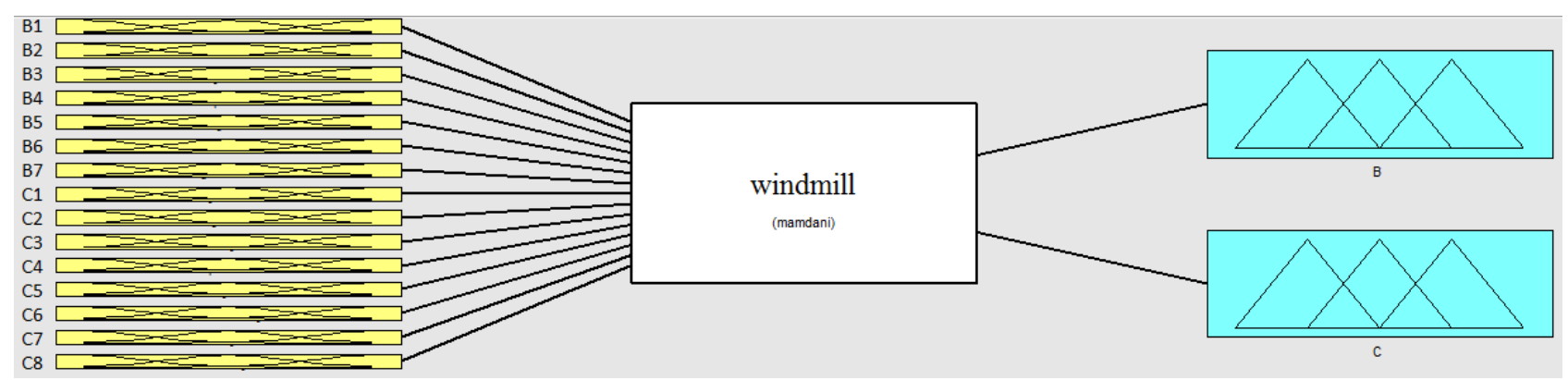

Fig. 4. Fuzzy input/output combination 
The fuzzy logic decision selection of the sites options was applied according to benefits and costs:

Benefits:

$\mathrm{B} 1=$ Wind resource,

$\mathrm{B} 2=$ Prevailing wind direction,

B3= Above ground level (AGL) (m),

B4= Site capacity,

B5= Site accessibility,

B6= Soil conditions,

$\mathrm{B} 7=$ Site elevation.
Costs:

$\mathrm{C} 1=$ Land cost,

$\mathrm{C} 2=$ Land roughness,

$\mathrm{C} 3=$ Temperature $\left({ }^{\circ} \mathrm{C}\right)$,

$\mathrm{C} 4=$ Cultural and environmental concerns,

C5=Aviation/Telecommunications conflicts,

C6 $=$ Nearby resident's concerns,

$\mathrm{C} 7=$ Site environmental issues,

$\mathrm{C} 8=$ Distance to transmission line $(\mathrm{m})$.

The fuzzy logic methodology is applied taking into account each site parameters for location Podveležje [8-10]. The inputs in tables 1 and 2 are considered to be the fuzzy variables, each variable can vary over a fixed range.

\begin{tabular}{|c|c|c|c|c|c|c|c|c|c|}
\hline & B1 & B2 & B3 & B4 & B5 & B6 & B7 & $\begin{array}{c}\text { Relative } \\
\text { weight }\end{array}$ & $\begin{array}{c}\text { Normalized } \\
\text { relative weight }\end{array}$ \\
\hline Podveležje (BiH) & 1 & 0.7 & 50 & 0.8 & 0.9 & 0.3 & 825 & 0.737 & 0.905 \\
\hline
\end{tabular}

Table 1. Overall fuzzy weights for the selected sites based on benefits

\begin{tabular}{|l|c|c|c|c|c|c|c|c|c|c|}
\hline & C1 & C2 & C3 & C4 & C4 & C6 & C7 & C8 & $\begin{array}{c}\text { Relative } \\
\text { weight }\end{array}$ & $\begin{array}{c}\text { Normalized } \\
\text { relative weight }\end{array}$ \\
\hline Podveležje (BiH) & 0.2 & 0.1 & 15 & 0.65 & 0.1 & 0.4 & 0.5 & 10 & 0.394 & 0.816 \\
\hline
\end{tabular}

Table 2. Overall fuzzy weights for the selected sites based on costs

The linguistic variables used in the fuzzy methodology are: Very low (VL), Low (L), Normal (N), High (H), Very high (VH), Poor, Marginal, Satisfactory, Good, Excellent, Rock, Mostly rock, Rock/soil, Mostly soil, Soil, Moderate, None, Extensive, Negligible, Minor, Average, Very close, Close, Not far, Far, Very far. Each fuzzy set is addressed as listed in Table 3.

\begin{tabular}{|c|c|c|c|c|c|c|c|c|}
\hline \multirow{2}{*}{ Parametres } & \multirow{2}{*}{ Symbol } & \multirow{2}{*}{$\begin{array}{c}\text { Variable } \\
\text { type }\end{array}$} & \multicolumn{5}{|c|}{ Linguistic variables } & \multirow{2}{*}{ Range } \\
\hline & & & $\mathbf{1}$ & 2 & 3 & 4 & 5 & \\
\hline Wind resource & B1 & INPUT & VL & $\mathrm{L}$ & $\mathrm{N}$ & $\mathrm{H}$ & $\mathrm{VH}$ & $0-1$ \\
\hline $\begin{array}{c}\text { Prevailing } \\
\text { wind direction }\end{array}$ & B2 & INPUT & Poor & $\begin{array}{c}\text { Margina } \\
1\end{array}$ & $\begin{array}{c}\text { Satisfactor } \\
y\end{array}$ & Good & $\begin{array}{c}\text { Excellen } \\
\mathrm{t}\end{array}$ & $0-1$ \\
\hline $\begin{array}{c}\text { Above ground } \\
\text { level }\end{array}$ & B3 & INPUT & VL & $\mathrm{L}$ & $\mathrm{N}$ & $\mathrm{H}$ & VH & $10-80 \mathrm{~m}$ \\
\hline Site capacity & B4 & INPUT & Poor & $\begin{array}{c}\text { Margina } \\
1\end{array}$ & $\begin{array}{c}\text { Satisfactor } \\
\mathrm{y}\end{array}$ & Good & $\begin{array}{c}\text { Excellen } \\
\mathrm{t}\end{array}$ & $0-1$ \\
\hline $\begin{array}{c}\text { Site } \\
\text { accessibility }\end{array}$ & B5 & INPUT & Poor & $\begin{array}{c}\text { Margina } \\
1 \\
\end{array}$ & $\begin{array}{c}\text { Satisfactor } \\
\mathrm{y}\end{array}$ & Good & $\begin{array}{c}\text { Excellen } \\
\mathrm{t}\end{array}$ & $0-1$ \\
\hline Soil conditions & B6 & INPUT & Rock & $\begin{array}{l}\text { Mostly } \\
\text { rock }\end{array}$ & Rock/Soil & $\begin{array}{l}\text { Mostly } \\
\text { soil }\end{array}$ & Siol & $0-1$ \\
\hline Site elevation & B7 & INPUT & VL & $\mathrm{L}$ & $\mathrm{N}$ & $\mathrm{H}$ & VH & $\begin{array}{c}0-2100 \\
m\end{array}$ \\
\hline Land cost & $\mathrm{C} 1$ & INPUT & VL & $\mathrm{L}$ & $\mathrm{N}$ & $\mathrm{H}$ & $\mathrm{VH}$ & $0-1$ \\
\hline $\begin{array}{c}\text { Land } \\
\text { roughness }\end{array}$ & $\mathrm{C} 2$ & INPUT & VL & $\mathrm{L}$ & $\mathrm{N}$ & & & $0-1$ \\
\hline Temperature & $\mathrm{C} 3$ & INPUT & None & $\begin{array}{c}\text { Moderat } \\
\mathrm{e}\end{array}$ & Extensive & & & $\begin{array}{l}-40- \\
40^{\circ} \mathrm{C}\end{array}$ \\
\hline $\begin{array}{c}\text { Cultural and } \\
\text { environmental } \\
\text { concerns }\end{array}$ & $\mathrm{C} 4$ & INPUT & None & $\begin{array}{c}\text { Moderat } \\
\mathrm{e}\end{array}$ & Extensive & & & $0-1$ \\
\hline
\end{tabular}




\begin{tabular}{|c|c|c|c|c|c|c|c|c|}
\hline \hline $\begin{array}{c}\text { Aviation/ } \\
\text { Telecommunic } \\
\text { ations conflicts }\end{array}$ & C5 & INPUT & None & $\begin{array}{c}\text { Moderat } \\
\mathrm{e}\end{array}$ & Extensive & & $0-1$ \\
\hline $\begin{array}{c}\text { Nearby } \\
\text { resident's } \\
\text { concerns }\end{array}$ & C6 & INPUT & Negligible & $\begin{array}{c}\text { Moderat } \\
\mathrm{e}\end{array}$ & Extensive & & & \\
\hline $\begin{array}{c}\text { Site } \\
\text { environmental } \\
\text { issues }\end{array}$ & C7 & INPUT & None & Minor & Average & Moderate & $\begin{array}{c}\text { Extensiv } \\
\mathrm{e}\end{array}$ & $0-1$ \\
\hline $\begin{array}{c}\text { Distance to } \\
\text { transmission } \\
\text { line }\end{array}$ & C8 & INPUT & Very close & Close & Not far & Far & Very far & $0-30 \mathrm{~km}$ \\
\hline & $\mathbf{B}$ & OUTPUT & $\mathbf{V L}$ & $\mathbf{L}$ & $\mathbf{N}$ & $\mathbf{H}$ & $\mathbf{V H}$ & $\mathbf{0}-\mathbf{1}$ \\
\hline & $\mathbf{C}$ & OUTPUT & $\mathbf{V L}$ & $\mathbf{L}$ & $\mathbf{N}$ & $\mathbf{H}$ & $\mathbf{V H}$ & $\mathbf{0}-\mathbf{1}$ \\
\hline
\end{tabular}

Table 3. Fuzzy sets

\section{Constructing fuzzy rules}

Sixty five rules were used in the current fuzzy method implementation to predict the most preferable options or option out of the Podveležje site.

Fuzzy logic enabled us to dense large amount of data, collected to compare between different sites, into a smaller set of variable rules, to make a decision in the basis of their merits and barriers to produce higher power output at low cost as well as to capture as maximum wind power as possible.

The benefit to cost ratio is shown in Table 4 .

\begin{tabular}{|c|c|c|c|c|}
\hline Site & $\begin{array}{c}\text { Normalized benefit relative } \\
\text { weight }\end{array}$ & $\begin{array}{c}\text { Normalized cost relative } \\
\text { weight }\end{array}$ & $\mathbf{B} / \mathbf{C}$ & $\begin{array}{c}\text { Normalized } \\
\mathbf{B} / \mathbf{C}\end{array}$ \\
\hline Podveležje $(\mathrm{BiH})$ & 0.905 & 0.816 & 1.109 & 0.671 \\
\hline
\end{tabular}

Table 4. Benefit to cost ratio

\section{Performing fuzzy interface}

Finally, the mapping process takes place to provide the final decision as shown in Figure 5.

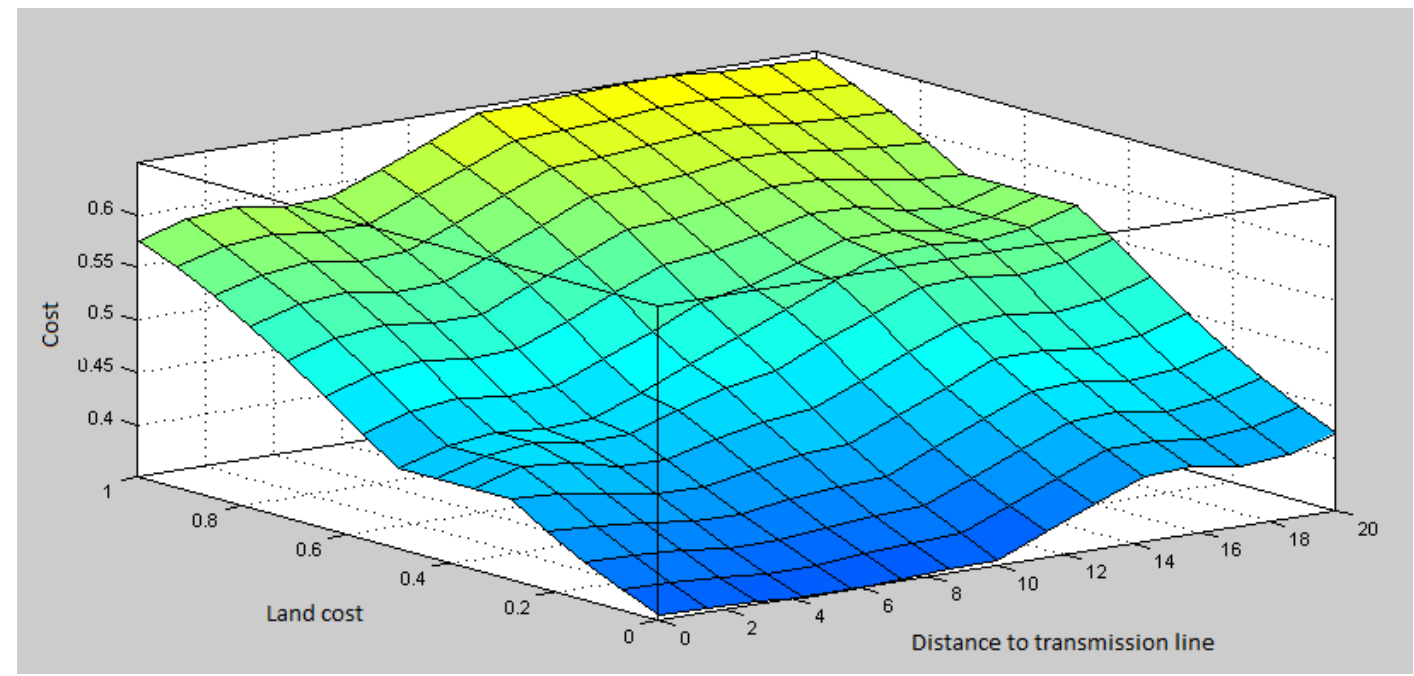

Fig. 5. Fuzzy implementation sequence

Defuzzification process assesses the outcome in the decision making process. The parameters are analyzed individually, and in this process it is possible to observe two parameters and decide which of them more influenced our results. 
This is especially important and helpful in choosing a location for a wind farms. It helps in determining the optimal location. For example in the case that we have two locations with similar parameters then based on those parameters which are different we can make analysis and bring the correct conclusion that the location is favorable.

Also, on the basis of this method it is possible to perform a number of conclusions. For example analysis parameters, land cost and distance to transmission line can be concluded that the land cost is much more important in the decision-making process (Figure 5). The image is clear that the parameter 8 (distance to transmission line) has very little effect, and its only effect is that if the transmission line is over a distance of $10 \mathrm{~km}$, or more than $10 \mathrm{~km}$ while any change in parameter $\mathrm{C} 1$ (land cost) leads to changes in the final results.

\section{Conclusion}

The purpose of this paper is to use fuzzy logic and MATLAB for predict the best location for wind farm.

In deciding the used 15 input parameters, where seven parameters presents benefits and eight parameters represents costs. Used a total of 65 rules for decision making.

This model includes all relevant parameters to determine the optimal location for the construction of a wind farm. The advantage of the model is the possibility of determining the advantages of a parameter to the second parameter to a certain value. It is notable that in some parameters higher changes their values do not lead to large differences in profitability of a wind farm until some parameters and their values minor changes lead to great changes in profitability.

For verification of our solutions, we used data on existing wind farm in Podveležje. Based on our model, we concluded that the choice of location in this case was quite good. Normalized benefit relative weight 0.905 , normalized cost relative weight 0.816 ), or by defined outputs it is between high and very high.

In further research is necessary to collect all the relevant information for potential locations where it is possible to build wind parks. These data would be used in the current model presented in this paper to determine the viability of investments in the wind park.

\section{References}

[1] http://www.gwec.net, (2016). GWEC-Global Wind 2015 Report, Accessed on: 2016-09-27

[2] Shata, A.S. \&Hanitsch, R. (2006). Evaluation of wind energy potential and electricity generation on the coast of Mediterranean Sea in Egypt, Renewable Energy, Vol.31, No.8, page numbers (1183-1202), 0960-1481

[3] Koçak, K. (2008). Practical ways of evaluating wind speed persistence, Energy, Vol.33, No.1, page numbers (6570), 0360-5442

[4] Herbert, G.M.; Iniyan, S.; Sreevalsan, E. \&Rajapandian, S.A. (2007). Review of wind energy technologies, Renewable and Sustainable Energy Reviews, Vol.11, No.6, page numbers (1117-1145), 1364-0321

[5] Lackner, M.A.; Rogers, A.L. \&Manwell, J.F. (2008). The round robin site assessment method: A new approach to wind energy site assessment, Renewable Energy, Vol.33, No.9, page numbers (2019-2026), 0960-1481

[6] Badran, O.; Abdulhad, E. \&El-Tous, Y. (2011). Fuzzy Logic Controller for Predicting Wind Turbine Power Generation, International Journal of Mechanical and Materials Engineering, Vol.6, No.1, page numbers (51-66), 2198-2791

[7] Study of Energetic sector in B\&H, Energetski institut Hrvoje Požar - Croatia, Soluziona - Spain, Ekonomski institut Banjaluka, - BH, Rudarski institut Tuzla - BH, 2008

[8] Elvir, Z.; Mehmed, B.; Fuad, Ć. \&Enes, S. (2008). Energy resources from wind energy in Bosnia \& Herzegovina, current state and prospects, 12 International Research/Expert Conference "Trends in the Development of Machinery and Associated Technology" TMT 2008, Istanbul, Turkey

[9] Behmen, M.; Zlomušica, E. \& Ćatović, F. (2004). The Influence of Electro-Supply Capacities on the State of the Environment in B\&H, Status and Perspectives, 8th International Research/Expert Conference Trend in the Development of Machinery and Associated Technology-TMT 2004, Neum, Bosnia and Herzegovina

[10] Ćatović, F.; Behmen, M. \& Zlomušica, E. (2004) Trends in the development of the electric power systems based on wind energy in world and in Bosnia and Herezegovina, Journal of Enviromental Protection and Ecology-Official Journal of the Balkan Enviromental Association (B.EN.A), Vol. 5, No.4, page numbers (836-840), 1311-5065

[11] Nyrkov, A; Chernyi, S.; Zhilenkov, A. \& Sokolov, S. (2016). The use of Fuzzy Neural Structures to Increase the Reliability of Drilling Platforms, Proceedings of the 26th DAAAM International Symposium, pp.0672-0677, B. Katalinic (Ed.), Published by DAAAM International, ISBN 978- 3-902734-07-5, ISSN 1726-9679, Vienna, Austria 